\title{
PEMUPUKAN SEMANGAT INTEGRASI NASIONAL MELALUI PENDIDIKAN SEJARAH DI SEKOLAH ${ }^{1}$ )
}

\author{
Singgih Tri Sulistiyono
}

\begin{abstract}
Abstrak
Saat ini lembaga sekolah sedang mengalami krisis civic education. Dalam hal ini, pendidikan sejarah merupakan salah satu alternatif yang perlu dipertimbangkan. Perspektif yang perlu dikembangkan adalah cross-cultural communication dan cultural reelativism. Disamping menekankan pandangan bahwa proses terbentuknya bangsa Indonesia tidak dapat dipisahkan dengan perkembangan historis hubungan lintas budaya antar kelompok etnis dan budaya yang ada di Nusantara, juga penggambaran sejarah hendaknya menghindarkan diri sejauh mungkin prasangka-prasangka kultural dan etnisitas. Pendidikan sejarah yang tepat akan memiliki nilai integratif bagi nasion Indonesia jika para guru sejarah memiliki kemampuan untuk mengajar dengan penekanan pada cross-cultural communication dan dengan menggunakan perspektif relativisme kultural.
\end{abstract}

\section{Kata kunci: Pendidikan Sejarah, Integrasi Nasional}

1) Tulisan ini diadaptasi dari makalah yang dipresentasikan pada Seminar Nasional "Peran Sejarah dalam Meningkatkan Daya Saing Bangsa," diselenggarakan oleh Prodi Pendidikan Sejarah IKIP PGRI Madiun, 12 Juni 2010.

Singgih Tri Sulistiyono adalah Guru Besar Sejarah Fakultas Ilmu Budaya Universitas Diponegoro Semarang. 


\section{Pendahuluan}

Kemerosotan kualitas kehidupan bersama sebagai suatu bangsa yang dikeluhkan oleh berbagai kalangan pada saat ini sebetulnya sudah muncul sejak tahun 1980-an. Berbagai sinyalemen adanya gejala 'merosotnya nasionalisme dan patriotisme', 'merosotnya sikap kepahlawanan', 'ancaman disintegrasi', ataupun 'merosotnya kesadaran berbangsa' pada waktu itu sudah mulai menjadi kekhawatiran banyak pihak. Adalah sangat ironis bahwa kekhawatiran tersebut muncul di tengah-tengah upaya pemerintah Orde Baru yang pada waktu itu sedang menggalakkan penataran P4 (Pedoman Penghayatan dan Pengamalan Pancasila), Departemen Pendidikan dan Kebudayaan yang sedang gencar mengampanyekan mata pelajaran PSPB (Pendidikan Sejarah Perjuangan Bangsa), dan dalam kondisi perekonomian yang sedang mengalami 'boom'.

Bahkan pada saat ini sinyalemen -sinyalemen tersebut ternyata bukan hanya rangkaian kata-kata belaka tetapi betul-betul telah menjadi kenyataan. Republik Indonesia yang belum genap berusia tujuh dekade ini sedang mengalami berbagai konflik. Konflik-konflik politik yang mengancam persatuan dan kesatuan bangsa Indonesia saat ini adalah masih belum tuntasnya persoalan disintegrasi bangsa sebagaimana yang (pernah) terjadi di Aceh, dan yang masih terjadi di Maluku, serta
Papua. Apapun alasannya, konflikkonflik yang berpotensi meruntuhkan integrasi bangsa itu merupakan cermin kerapuhan nasionalisme dan patriotisme bangsa Indonesia. Balum lagi adanya berbagai konflik sosial yang sewaktuwaktu dapat mencuat ke permukaan sebagaimana yang pernah terjadi di Kalimantan, Poso, Ambon dan sebagainya. Fenomena yang tidak kalah membuat hati menjadi 'miris' (tidak sekedar terusik) adalah adanya praktik-praktik korupsi dan 'mafianisme' dalam kehidupan bersama sebagai sebuah komunitas bangsa yang mencerminkan adanya 'proses pembusukan' (rotting process) yang jika tidak segera diantisipasi akan betul-betul menghacurkan diri sendiri.

Dalam kondisi yang seperti itu, pelajaran sejarah biasanya diposisikan sebagai 'tertuduh'. Seringkali pendidikan sejarah di sekolah dianggap telah gagal membangkitkan semangat patriot-isme, nasionalisme dan integrasi bangsa. Pada masa Orde Baru, 'kegagalan' pelajaran sejarah barang-kali disebabkan oleh terlalu benyaknya kepentingan penguasa yang 'dititipkan' pada mata pelajaran tersebut. Hanya buku sejarah yang 'direstui' pemerintah saja yang boleh diedarkan dalam masyarakat. Dengan demikian ketika orang menyaksikan sendiri adanya kesenjangan antara perilaku pemerintah dengan substansi pelajaran sejarah (dan Pendidikan Moral Pancasila) maka yang terjadi 
bukanlan 'pemupukan' tetapi 'pembusukan' nasionalisme dan integrasi bangsa. Ketika Orde Baru runtuh, maka 'kewibawaan' pela-jaran sejarah dan berbagai mata pelajaran civic education lain juga ikut ambruk, karena semuanya dianggap bagian kebobrokan rezim itu.

Gejala tersebut menunjukkan bahwa telah terjadi distorsi fungsi matapelajaran sejarah sebagai civic education. Demikian juga, materi pelajaran sejarah yang kurang menyentuh akar kepribadian segenap bangsa kurang efektif untuk membangkitkan kesadaran sejarah (historical consciousness) (Ballard, 1971). Di samping itu, pelajaran sejarah telah sangat diwarnai oleh ranah politik daripada sosial budaya. Padahal sesungguhnya persoalan integrasi bangsa banyak diwarnai oleh proses sosial budaya yang telah memakan waktu yang setua usia masyarakat Nusantara itu sendiri. Kini, banyak orang yang merasa risau ketika berbagai persoalan internal yang terkait dengan ancaman disintegrasi bangsa dan national and character building mencuat keluar dan ternyata tidak mudah untuk diselesaikan. Apalagi kekuatan eksternal yang berupa gelombang globalisasi dan neoliberalisme semakin lama semakin agresif dalam mengikis nasionalisme dan integrasi bangsa serta peran negara dalam mengatur masyarakat. Semua itu (seharusnya) menyadarkan kepada segenap elemen bangsa tentang perlunya semacam civic education yang secara internal mampu memupuk semangat kebersamaan sebagai sebuah bangsa dalam meng- antisipasi secara positif ekspansi globalisasi dan neo-liberalisme.

Dengan melihat persoalan yang begitu besar, pertanyaan yang patut diajukan adalah: masih adakah harapan untuk menegakkan kembali kewibawaan pelajaran sejarah dalam konteks nation and character building serta untuk kepentingan integrasi bangsa? Bagaimanakah cara untuk memasukkan pelajaran atau hikmah nilai-nilai dan semangat integrasi nasional itu di dalam materi pendidikan sejarah di sekolah? Makalah ini akan mendeskripsikan pentingnya pendidikan sejarah dalam pembentukan sikap siswa khususnya dalam mengaktualisasikan nilai-nilai integrasi bangsa. Selain itu tulisan ini juga akan berbicara mengenai perspektif yang perlu dikembangkan dalam pembelajaran materi sejarah di sekolah dalam konteks integrasi bangsa.

\section{Landasan Konseptual: Pendidikan Sejarah dan Pembentukan Sikap}

Pentingnya pendidikan sejarah dalam pembentukan watak dan sikap anak didik tidak bisa dipungkiri. Pendidikan sejarah di sekolah bukan hanya sekedar berfungsi untuk meningkatkan kemampuan kognitif tetapi juga berfungsi dalam proses pembentukan afektif dan psikomotor. Dengan pendidikan sejarah, peserta didik tidak hanya menguasai materi dan substansi sejarah tetapi juga mampu memahami dan mengerti masa kini atas dasar pemahaman terhadap masa lampau. Dengan demikian 
sebetulnya siswa tidak hanya belajar sejarah (learning history) tetapi juga harus belajar dari sejarah (learning from history). Pemahaman yang demikian ini akan memberikan nilai lebih kepada pembentukan sikap dan prilaku siswa dalam kerangka memahami kondisi masyarakatnya di masa sekarang dan di masa yang akan datang. Siswa dapat belajar dari peristiwa-peristiwa masa lampau baik dari kejayaan maupun kekalahan (Collingwood, 1961). Hal itu juga sesuai dengan apa yang dikatakan Carr bahwa belajar sejarah pada hakekatnya adalah dialog yang terus-menerus antara masa kini dengan masa lampau (Carr, 1972).

Pendidikan sejarah akan menjadi salah satu sarana untuk menciptakan kesadaran sejarah. Dalam tataran kebangsaan, kesadaran sejarah dapat merupakan suatu hal yang subyektif dalam arti berkaitan dengan pengalaman dan penghayatan anak bangsa terhadap masa lampau bangsanya. Kesadaran sejarah yang ditunjang oleh pengetahuan masa lampau yang obyektif akan menimbulkan empati terhadap bangsanya dengan cara membayang dan menghidupkan kembali tindakan-tindakan manusia pada masa lampau (Hughes, 1964). Untuk selanjutnya, empati ini akan membangkitkan keingintahuan anak bangsa untuk menggali lebih dalam perjalanan bangsanya di masa lampau dalam rangka untuk menemukan jawaban dari pertanyaan mengapa segala sesuatu menjadi seperti apa yang terlihat pada masa kini. Anak bangsa yang memiliki kesadaran sejarah akan mencari jawabannya dengan belajar sejarah, sebagaimana yang pernah didengungkan oleh Bung Karno: 'jangan sekali-kali meninggalkan sejarah (jasmerah).' Mungkin setelah itu ia akan menjadi lebih arif dan dapat memberikan sumbangan pemikiran terhadap masa depan bangsa.

Bagi Indonesia saat ini, pendidikan sejarah di sekolah secara tepat adalah merupakan sesuatu yang tidak bisa ditawar-tawar lagi. Dalam hal ini pendidikan sejarah hendaknya memiliki relevansi dan kepentingan masa kini. Hal ini terkait dengan perubahan-perubahan besar yang terjadi dalam kehidupan berbangsa dan bernegara pascareformasi. Selain itu krisis-krisis politik yang mengancam integrasi nasional juga perlu diantisipasi dengan pendidikan sejarah. Gejala disintegrasi nasional merupakan problem kebangsaan yang paling serius yang sedang dihadapi oleh bangsa Indonesia (Lapian, 2003; Sulistiyono, 2003). Gejala disintegrasi ini di samping memiliki akar secara historis, juga disebabkan oleh pelaksanaan Otonomi Daerah yang memiliki kcenderungan keluar dari koridor dan semangat integrasi bangsa (Mardiyanto, 2003; Poelinggomang, 2003).

Dalam konteks itu, pendidikan sejarah dapat berfungsi sebagai wahana sosialisasi dan enkulturasi nilai-nilai masyarakat dan bangsa. Dalam hal ini sosialisasi dapat dimaknai sebagai proses menanamkan dan mengembangkan/ menyebarluaskan nilai-nilai sejarah dan budaya kepada anggota masyarakat (Soerjono Soekanto, 
1990). Adapun enkulturasi lebih dimaknai sebagai proses mempelajari nilai-nilai kebudayaan oleh seseorang (Ariyono Suyono, 1985). Dengan proses-proses ini diharapkan para peserta didik mengalami perubahan untuk dapat memahami dan menerima serta melaksanakan nilai-nilai budaya yang diakui dan diharapkan oleh masyarakatnya. Sudah barang tentu perubahan ini dapat dilihat dari peranan yang dimainkannya dalam kehidupan masyarakat dan bangsanya. Dengan belajar sejarah, peserta didik dapat menempatkan diri secara proporsional dalam masyarakatnya. Di samping itu mereka dapat memanfaatkan nilai-nilai sejarah untuk kepentingan kehidupan ke-kinian. Sejarah bukan untuk sejarah itu sendiri, bukan untuk orang-orang yang telah mati, tetapi sejarah untuk masa kini dan masa depan (Aron, 1959).

Dalam kaitannya dengan pendidikan sejarah nasional, Sartono Kartodirdjo mengatakan bahwa fungsi pendidikan sejarah adalah: (1) membangkitkan perhatian serta minat kepada sejarah tanah air, (2) mendapatkan inspirasi dari cerita sejarah, (3)memupuk alam pikiran ke arah kesadaran sejarah, (4) memberi pola pikiran ke arah cara berpikir rasional dan penghargaan terhadap nilai-nilai bangsanya (Kartodirdjo, 1982). Dalam kaitan itu pula peranan guru sejarah sangat besar untuk memberikan motivasi kepada peserta didik untuk senang mempelajari sejarah bangsanya (Dickinson \& Lee, 1980).
Peranan pendidikan sejarah sebagai sarana untuk memperkokoh integrasi nasional juga dikatakan oleh Cristine Drake. Ia mengatakan bahwa ada lima hal yang dapat memperkuat integrasi nasional yaitu: (1) pengalaman sejarah yang sama sebagai suatu bangsa, (2), simbolsimbol sosial budaya yang diakui bersama seperti bahasa, bendera, lagu kebangsaan dan sebagainya, (3) interaksi di antara bebagai kelompok sosial dalam masyarakat, (4) ketergantungan ekonomi antar daerah. Dengan demikian pendidikan sejarah sebagai pengalaman bersama anak bangsa akan bisa memperkuat integrasi nasional (Drake, 1988).

\section{Signifikansi Pendidikan sejarah (Nasional)}

Salah satu persoalan besar yang sedang dihadapi oleh bangsa Indonesia saat ini adalah keberlangsungan Indonesia itu sendiri, yaitu apakah Indonesia dalam wujudnya yang seperti sekarang ini dapat dipertahankan di masa yang akan datang. Persoalan yang sangat mendasar ini erat kaitannya dengan komitmen segenap bangsa Indonesia apakah masih ingin melangsungkan kehidupan bersama sebagai sebuah nasion atau tidak. Di beberapa tempat masih dapat disaksikan adanya beberapa gerakan politik dan mungkin juga gerakan bersenjata untuk memisahkan diri dari NKRI (Negara Kesatuan Republik Indonesia) sebagaimana yang terjadi di Maluku dan Papua. Selain itu juga masih sering terdengar berita adanya 
konflik sosial yang berbau SARA (suku, agama, dan ras) di beberapa tempat di Indonesia.

Persoalan lain yang juga masih dihadapi oleh bangsa Indonesia adalah dampak dan buntut dari krisis moneter (krismon) yang terjadi sejak akhir tahun 1997. Krisis moneter itu diikuti oleh berbagai krisis seperti krisis politik, krisis kultural, dan krisis kepercayaan terhadap pemimpin, sehingga ada yang menyebutnya sebagai 'kristal' atau krisis total. Seperti diketahui bahwa krisis ekonomi itu telah ikut pula melahirkan gerakan reformasi yang mulai merebak sejak tahun 1998. Di tengah carut-marut kehidupan bangsa dan adanya ancaman disintegrasi tersebut, ironi dalam 'dunia sejarah' juga terjadi yaitu dengan 'dicampakkannya' materi pendidikan sejarah nasional. Padahal salah satu tujuan utama pendidikan sejarah nasional ini adalah untuk membangkikan kesadaran diri sebagai sebuah bangsa yang lahir dari hasil proses sejarah yang panjang.

Pentingnya kedudukan Sejarah Nasional perlu dipahami dalam kaitannya dengan situasi yang dihadapi oleh bangsa Indonesia ketika konsep Sejarah Nasional itu lahir pada tahun 1950-an. Tahuntahun 1950-an telah memberikan pengalaman-pengalaman baru kepada segenap elemen bangsa Indonesia dalam kehidupan bersama sebagai sebuah nation: perang kemerdekaan melawan tentara Sekutu dan Belanda, jatuhbangunnya NKRI, berbagai konflik daerah dan gerakan separatisme, serta pemberontakan, keterlibatan
Belanda dalam pemberontakan RMS (Republik Maluku Selatan), keterlibatan Amerika dalam Pemberontakan PRRI/PERMESTA, penguasaan Irian Barat oleh Belanda, dan sebagainya. Semua itu telah menempa semangat nasionalisme yang tinggi di kalangan bangsa Indonesia termasuk para sejarawan. Dalam hubungan ini dapat dipahami jika semangat dekolonisasi historiografi sangat mewarnai Seminar Sejarah Nasional I yang diselenggarakan di penghujung tahun 1957.

Dalam seminar itu hampir semua peserta mencurahkan perhatiannya untuk merumuskan landasan filosofis dan metodologis sejarah Indonesia. Pada waktu itu dirasakan betapa pentingnya mencari dan neneguhkan identitas bangsa Indonesia yang berasal dari kajian sejarah. Sejarawan Sartono Kartodirdjo menggagas konsep Sejarah Nasional yang akan menggambarkan pasang-surut proses formasi nation Indonesia. Memang nation Indonesia merupakan realitas baru, namun tidak muncul secara tiba-tiba pada awal abad XX atau bahkan baru pada tahun 1945. "Proses menjadi Indonesia" itu sudah berlangsung berabad-abad yang lalu. Menurut Sartono, "network" merupakan elemen penting dalam proses formasi nasion Indonesia. Ia mengatakan (Kartodirdjo, 1988):

"Sejarah Nasional Indonesia sesungguhnya dapat dipandang sebagai proses perkembangan yang secara lambat laun dan kontinu mewujudkan integrasi, 
sejak zaman prasejarah sampai masa kini yang akhirnya menghasilkan bentuk integrasi seperti terwujud pada kesatuan nasional dewasa ini."

Oleh karena itu, perspektif Indonesiasentris sangat diperlukan dalam menulis Sejarah Nasional agar peran elemen-elemen sosio-kultural yang kemudian menjadi nation Indonesia dapat diungkapkan. Jadi pada tahun 1950-an itu historiografi Indonesia sudah menjalankan fungsinya untuk ikut menyelesaikan masalah-masalah aktual yang sedang dihadapi bangsa Indonesia terutama dalam pencarian identitas sebagai sebuah nation baru yang sangat plural secara kultural.

Apa yang menjadi pertanyaan adalah: Apakah sudah saatnya "Sejarah Nasional" dicampakkan begitu saja? Apakah hanya karena campur tangan pemerintah Orde Baru terhadap Sejarah Nasional kemudian jenis sejarah ini dihapus begitu saja? Apakah bangsa Indonesia tidak memerlukan Sejarah Nasional lagi? Apakah semestinya Sejarah Nasional masih diperlukan dengan perubahan-perubahan pada aspek metodologis? Pendek kata, sederet pertanyaan dapat diajukan di sini. Jika diingat bahwa Sejarah Nasional merupakan sejarah yang menggambarkan perkembangan ke arah integrasi Indonesia, maka sesungguhnya Sejarah Nasional itu masih diperlukan (Kartodirdjo, 2005). Hal ini terkait erat dengan kenyataan bahwa integrasi bangsa merupakan konsep yang dinamis. Integrasi nasional sebuah bangsa dapat mengalami kehancuran jika segenap elemen sebuah bangsa tidak memiliki komitmen lagi untuk hidup bersama sebagai sebuah bangsa. Kehancuran Uni Soviet dan Yugoslavia telah memberikan pelajaran berharga mengenai in-tegrasi nasional. Selama persatuan Indonesia masih didambakan oleh bangsa Indonesia maka selama itu pula Sejarah Nasional masih signifikan.

Kedudukan Sejarah Nasional sebagai refleksi pengalaman bersama (common experience) sangat penting karena dari sejarah ini lah akar budaya, politik, dan struktur ekonomi dari suatu bangsa dapat ditemukan (Drake, 1989). Apalagi jika diingat bahwa integrasi nasional Indonesia masih menghadapi tantangan yang berat mengingat selalu saja ada keinginan berbagai kelompok untuk memisahkan diri dari NKRI. Memang harus diakui bahwa nasion Indonesia merupakan realitas baru, namun realitas itu tidak datang begitu saja dari langit, tetapi melalui proses historis yang panjang yang mencerminkan cross-cultural communication di antara berbagai elemen yang kemudian membentuk nasion Indonesia (a process to be Indonesia) (Klooster, 1992). Dengan demikian, Sejarah Nasional tidak perlu disingkirkan hanya karena kontaminasi kepentingan politik Orde Baru. Dengan perpektif baru dan pendekatan baru, Sejarah Nasional dapat dikembangkan untuk memupuk persatuan dan nasionalisme yang berlandaskan pada dialog, keadilan dan kesejahteraan.

Jika dalam pendidikan sejarah nasional tidak semua fakta memiliki 
nilai, namun hanya fakta-fakta yang merajut benang merah ke-Indonesiaan saja yang berguna, maka Sejarah Indonesia memberikan ruang yang luas kepada fakta-fakta sejarah yang terjadi di ruang yang kemudian menjadi wilayah Indonesia. Sejarah Indonesia tidak hanya dapat mencakup segala aspek kehidupan masyarakat Indonesia baik di bidang politik, ekonomi, sosial, budaya, dan sebagainya dengan cakupan periode yang tidak terbatas, tetapi juga dapat mencakup sejarah berbagai daerah yang termasuk dalam wilayah negara Indonesia. Dengan demikian, dapat dikatakan bahwa apa yang disebut sebagai sejarah lokal sebetulnya juga merupakan bagian dari sejarah Indonesia. Harus dicacat bahwa Sejarah Nasional bukan merupakan penjumlahan dari sejarah lokalsejarah lokal yang berserakan di sana-sini. Proses formasi nation Indonesia menjadi titik tekan utama sejarah nasional (Kartodirdjo, 2005).

\section{Perspektif Integrasi Nasional dalam Pendidikan sejarah}

Menarik sekali apa yang diungkapkan oleh Drake bahwa pendidikan sejarah memiliki peran sebagai sarana untuk memperkokoh integrasi nasional. Di samping itu, masih ada beberapa faktor yang lain yang dapat memperkuat integrasi bangsa, antara lain adalah interaksi yang intensif di antara bebagai kelompok sosial dalam masyarakat (Drake: 1989). Dalam hubungan itu, perlu perspektif tertentu dalam pendidikan sejarah agar dapat menjalankan peran dalam proses nation and character building dan untuk memperkuat integrasi bangsa. Paling tidak ada dua perspektif yang perlu mendapatkan penekanan pembelajaran materi sejarah untuk memperkuat integrasi nasional, yaitu perspektif cross-cultural communication dan cultural relativism.

\section{Cross-cultural Communication}

Mengingat baik secara historis maupun geografis, Indonesia merupakan negara plural dengan bentangan geografis yang sangat luas dan beraneka ragam yang dipisahkan oleh laut dan selat, maka unsur komunikasi lintas budaya merupakan bagian yang inheren dalam sejarah Indonesia. Apa yang dinamakan bangsa Indonesia sesungguhnya terbentuk melalui proses cross-cultural communication (komunikasi lintas budaya). Suatu kenyataan yang tidak dapat diingkari bahwa Indonesia merupakan satu kesatuan politik yang mengikat beribu-ribu pulau dan beratus-ratus suku bangsa. Hal itu menunjukkan adanya perkembangan dinamika faktor hubungan antar pulau, antar suku bangsa, antar kelompok sosial, dan antar bangsa yang telah memainkan peranan yang sangat penting dalam proses integrasi bangsa. Dalam hubungan ini perspektif hubungan lintas budaya perlu mendapatkan penekanan dalam pendidikan sejarah sebagai wahana memupuk integrasi bangsa.

Komunikasi lintas budaya memiliki hubungan yang erat dengan 
sebuah proses terbentuknya bangsa Indonesia atau 'proses menjadi Indonesia' (a process to be Indonesia). Jadi perlu disadari bahwa secara legal dan secara politik memang Indonesia sudah ada, tetapi secara kultural sebagai sebuah bangsa, Indonesia masih dalam suatu proses yang tidak menutup kemungkinan akan gagal di tengah jalan. Dalam hubungan itu, apa yang disebut sebagai cross cultural communication yang menghubungkan berbagai kelompok etnik, unsur-unsur sosial dan lokalitas di Nusantara menjadi sangat penting kedudukannya. Mengingat persoalan-persoalan disintegrasi yang sedang dihadapi bangsa Indonesia saat ini maka perlu dicari perspektif baru yang menyangkut hubungan antara wilayah, kesatuan sosial dan politik. Dalam hubungan itulah akar-akar sosial, politik, ekonomi dan budaya yang menjadi landasan hubungan antar wilayah baik dalam bentuk friendship (persahabatan, diplomasi) maupun dalam bentuk conflict dan penyelesaiannya (managemen kon-flik) perlu diidentifikasi dan dijelaskan dengan baik kepada para siswa.

Dengan pendidikan sejarah Indonesia yang menekankan segi komunikasi lintas budaya, diharapkan pelajaran bisa diambil untuk memperkaya wacana dalam pengembangan model komunikasi lintas budaya pada masa sekarang dan yang akan datang. Dalam hubungan itu fenomena pola-pola komunikasi lintas budaya pada masa pra-kolonial perlu dipahami justru pada periode itu kekuatan politik pribumi saling berinteraksi dan berbenturan namun pada akhirnya menemukan bentuk-bentuk keseimbangannya.

Meskipun secara silih berganti, kekuatan-kekuatan politik juga saling berkonflik dan berakomodasi, namun ada saat-saatnya di mana gelombang pengaruh kebudayaan dan agama mempersatukan mereka. Kebudayaan dan agama menjadi semacam identitas dari komunitas yang mungkin secara etnik berbeda. Hal ini bisa dilihat dari proses penyebaran agama Hindu, Budha, Islam yang telah berkembang menjadi identitas bersama yang relatif mampu mengatasi koridor kesukuan. Dalam konteks itu pemahaman mengenai perkembangan kerajaan-kerajaan di Indonesia dan model-model komunikasi lintas budaya yang mereka kembangkan sangat relevan dengan kondisi Indonesia saat ini yang juga sedang mensyaratkan adanya komunikasi litas budaya yang intensif. Di samping itu kota-kota yang menjadi pusat-pusat kerajaan-kerajaan maritim juga merupakan pusat-pusat perdagangan dunia. Sebagai pusat perdagangan dunia maka sudah barang tentu kota-kota ini bersifat kosmopolitan. Sifat kosmopolitan dari kota-kota ini memungkinkan terkondisinya suasana koeksistensi damai di antara komunitas-komunitas dan sikap toleransi yang relatif tinggi. Seperti diketahui bahwa sejak perdagangan antarpulau dan perdagangan internasional berkembang di Nusantara, kota-kota pantai menjadi titik-titik simpul dalam perdagangan itu dan menjadi rendesvous serta tempat tinggal para 
pedagang, baik pedagang lokal maupun pedagang dari mancanegara.

Dalam konteks itulah pemahaman akar-akar integrasi nasional dari kajian historis periode prakolonial akan memberikan kemungkinan yang luas bagi penemuan model yang ideal bagi komunikasi lintas budaya yang merupakan unsur penting dalam mewujudkan integrasi bangsa. Dengan demikian, untuk kepentingan civic education, masih perlu adanya sejarah nasional yang menekankan kepada proses untuk menjadi Indonesia atau dengan kata lain proses-proses kemasyarakatan yang mangantarkan kepada terwujudnya integrasi nasional Indonesia. Sudah barang tentu di dalam proses itu kejadian-kejadian yang terjadi sangat bervariasi yaitu berupa kompetisi, konflik, dan akomodasi.

Unsur yang paling penting dalam penonjolan alur dari proses sejarah Indonesia adalah keseimbangan antara unsur ekspansi (perkembangan) dan integrasi dalam setiap fenomena dan proses historis. Segi ekspansi banyak menyangkut soal perkembangan dan kemajuan yang dicapai oleh suatu komunitas tertentu baik sebagai kesatuan geografis maupun kesatuan politis. Aspek perkembangan dan kemajuan itu bisa diacukan dengan muncul, berkembang, dan runtuhnya kesatuan-kesatuan politik yang menyebar di wilayah kepulauan Indonesia, baik dalam kurun yang bersamaan maupun dalam waktu yang bergantian.

Sementara itu, penonjolan segi integrasi dalam pendidikan sejarah Indonesia berarti penonjolan pada proses pembentukan jaringan (network) yang merefleksikan interrelasi di antara unsur-unsur sosial dalam masyarakat atau interkomunikasi lintas budaya masyarakat Indonesia. Kawasan perairan Indonesia merupakan suatu sistem network yang terdiri dari beberapa sub-network dari aktivitas perdagangan, politik, kebudayaan dan sebagainya. Sudah barang tentu aktivitas ini menggunakan jalur pelayaran sebagai sarananya yang memungkinkan terjadinya suatu fenomena yang oleh Curtin (1998) disebut sebagai trade diasporas (diaspora perdagangan). Dalam hubungan itu penting untuk memahami route perdagangan dan hubungan di antara pusat perdagangan (pasar), arah perdagangan, komoditi yang diperdagangkan, dan sebagainya yang semuanya itu bisa menggambarkan sebuah jaringan yang merupakan faktor yang mendasar dari proses integrasi. Dengan demikian jaringan ini melibatkan pusat-pusat perdagangan yang merupakan market place yang biasanya merupakan kota-kota pelabuhan yang merupakan titik-titik simpul dari suatu jaringan perdagangan.

Suatu jaringan perdagangan memiliki cakupan yang bervariasi, bisa mencakup hanya di tingkat lokal dan ada juga yang memiliki cakupan tingkat internasional. Jaringan ini biasanya berhubungan dengan mobilitas barang, modal, dan tenaga kerja di antara daerah dan pelabuhan. Seringkali juga terjadi bahwa jaringan lokal merupakan bagian dari jaringan perdagangan 
internasional karena perdagangan internasional ini merupakan faktor penting yang menghubungkan berbagai kesatuan geografis yang berbeda. Jadi dengan demikian paradigma integrasi yang bertumpu pada komunikasi lintas budaya perlu dijadikan sebagai perspektif dalam pendidikan sejarah.

\section{Perspektif Cultural Relativism}

Kompleksitas komposisi etnik dalam konstruksi nasion Indonesia memang merupakan sesuatu yang unik dan indah. Indonesia barangkali merupakan salah satu negara yang paling plural di dunia dari segi etnisitas. Komposisi yang demikian itu juga merupakan daya tarik yang luar biasa yang sulit dicari bandingannya. Namun demikian komposisi etnisitas yang sangat plural ini juga mengandung potensi konflik. Hal ini pernah dirasakan oleh pujangga Mpu Tantular yang mengungkapkan adagium: bhinneka tunggal ika yang sering diterjemahkan dengan istilah unity in diversity atau berbeda-beda tetapi tetap satu. Di samping mencerminkan realitas pluralisme pada masa kejayaan Majapahit (dari segi agama dan etnisitas), adagium itu juga mengandung sebuah harapan dan cita-cita mengenai sebuah masyarakat yang meskipun plural tetapi tetap merasa satu dan dapat bersatu. Jadi ungkapan itu juga mengandung idealisme mengenai masyarakat yang dicita-citakan atau masyarakat yang dibayangkan yang oleh Ben Anderson (1991) disebut sebagai imagined community.

Seperti diketahui bahwa apa yang disebut sebagai nasion Indonesia sesungguhnya terdiri dari ratusan etno-nasion. Sebelum mereka 'dipaksa' untuk berhimpun menjadi sebuah nasion Indonesia, mereka sudah memiliki bentukbentuk kesetiaan tertentu yang merefleksikan kecintaan terhadap daerah dan kelompok etnisnya sendiri. Masing-masing kelompok etnis memiliki identitas budaya sendiri-sendiri. Tiap-tiap kelompok etnik memiliki perasaan etnosentris sendiri-sendiri, sebuah perasaan kelompok dalam (in-group feeling) yang memandang kelompok etnik sendiri lebih hebat daripada kelompok etnik lain. Dengan demikian perasaan saling mencurigai selalu terbuka untuk terjadi dalam kehidupan baru semenjak nasion Indonesia diintrodukasikan. Dalam hubungan itu, apa yang disebut sebagai nasion Indonesia adalah sebuah nasion yang dicita-citakan sebagaimana yang diungkapkan oleh Anderson. Apa yang disebut sebagai nasion Indonesia sebetulnya masih dalam sebuah proses, a process to be Indonesia. Ada dua kemungkinan yang dapat terjadi dengan proses itu: pertama, proses itu mengalami keberhasilan sehingga cita-cita menjadi sebuah bangsa Indonesia yang bersatu dapat terealisasi; kedua, proses itu dapat mengalami kegagalan dengan akibat tidak pernah ada lagi sebuah bangsa yang bernama bangsa Indonesia. Kegagalan seperti itu pernah dialami 
oleh bangsa Yugoslavia dan Uni Soviet.

Dalam kaitan dengan peran pendidikan sejarah dalam pemupukan integrasi bangsa Indonesia, pertanyaan pokok yang dapat diajukan bukan lagi mengenai sejauhmana peran sejarah dalam penguatan integrasi bangsa, tetapi perspektif apa yang seharusnya digunakan oleh para guru sejarah dalam mengajarkan sejarah. Mengingat begitu kompleksnya latar belakang sosial dan etnisitas masyarakat Indonesia, maka perspektif cultural relativism atau relativisme budaya merupakan salah satu alternatif dalam mengajar sejarah agar memiliki daya integratif dan dapat mengurangi prasangka etnik (ethnic prejudice). Prasangka etnik dalam penuturan sejarah itu kadang-kadang muncul, misalnya tentang sinyalemen adanya penuturan sejarah Indonesia yang masih bersifat Jawa sentris.

Relativisme budaya merupakan prinsip di nana kepercayaan dan tindakan seseorang harus diintepretasikan dalam kerangka kebudayaannya sendiri serta memiliki keeterbatasan dalam di-mensi waktu dan tempat. Prinsip relativisme budaya juga mencakup pendirian bahwa kepercayaan dan tingkah laku masyarakat hanya dapat dipahami dalam konteks sejarah dan kebudayaan dari masyarakat yang bersangkutan.

Prinsip relativisme kultural ini muncul setelah Perang Dunia I ketika etnosentrisme Barat berkembang pesat. Pada waktu itu etnosentrisme mewujud dalam bentuk-bentuk yang sangat jelas, di mana seseorang, misalnya, yakin bahwa karya seni masyarakat tertentu merupakan seni yang paling indah, masyarakat tertentu memiliki nilai luhur yang paling tinggi, atau memiliki kepercayaan yang paling benar. Relativisme budaya ini pada awalnya berkembang di Amerika yang merupakan negara yang demokratis. Selama masa di antara dua perang dunia, para antropolog Amerika menggunakan prinsip cultural relativism sebagai alat utama untuk menolak klaim Barat (Eropa) mengenai universalitas dan untuk menyelamatkan budaya-budaya nonBarat yang sangat terancam dengan perkembangan konflik yang dapat melahirkan perang besar. Setelah Perang Dunia II, prinsip relativisme budaya ini semakin berkembang pesat, bahkan hal itu juga menjadi prinsip dasar bagi aliran postmodernisme.

Penggunaan prinsip relativisme budaya sebagai salah satu perspektif dalam pendidikan sejarah berarti penggunaan prinsip ini sebagai sebuah sikap intelektual. Hal ini terutama menyangkut sikap dan pendirian bahwa peristiwa-peristiwa sejarah harus dipahami berdasarkan konteks perkembangan sosiokultural masyarakat yang bersangkutan. Selain itu, sikap intelektual ini juga mencakup upaya untuk menghindarkan diri sejauh mungkin dari prasangka-prasangka kultural dan etnisitas ketika orang harus berbicara peristiwa-peristiwa sejarah yang berhubungan dengan masyarakat di luar etniknya. Pendek kata pendidikan sejarah akan memiliki nilai integratif bagi nasion 
Indonesia jika para guru memiliki kemampuan untuk mengajarkannya dengan perspektif cross-cultural communication dan relativisme kultural. Jadi, di samping memiliki ketajaman historical mindedness para guru sejarah perlu memiliki sikap intelektual menghargai nilai-nilai budaya dari kesatuan budaya di luar etniknya. Para guru sejarah hendaknya menghindarkan diri dari sikap etnosentrisme yaitu sikap yang menggunakan standar budaya etniknya sendiri untuk menilai budaya kelompok etnik lain.

Dengan demikian di dalam menggambarkan a process to be Indonesia dalam konteks crosscultural communication, para guru tidak menampilkan gambaran sejarah yang berpihak atau sebaliknya mengabaikan salah satu atau beberapa budaya/kelompok etnik tertentu. Komunikasi lintas budaya itu perlu digambarkan secara wajar, artinya dalam proses sejarah, hubungan lintas budaya itu dapat mencakup perdagangan, pelayaran, diplomasi, peperangan, penyebaran agama dan sebagainya. Namun demikian hal itu tidak perlu disertai dengan justifikasi bahwa budaya etnik tertentu lebih tinggi atau lebih 'beradab' daripada yang lain. Bahwa pada akhirnya hubungan lintas budaya itu menghasilkan proses asimilasi, akulturasi, adopsi, dan sebagainya adalah suatu proses yang alamiah yang merupakan bagian dari 'process to be Indonesia'.

\section{Penutup}

Dari uraian di atas dapat disimpulkan bahwa ada beberapa alasan mengapa perlu adanya revitalisasi pendidikan sejarah sebagai civic education dalam rangka memperkuat integrasi nasional. Pertama, secara geografis Indonesia merupakan kawasan kepulauan terbesar di dunia. Kawasan yang demikian luas ini dihuni oleh berbagai kelompok etnik yang selama berabad-abad telah saling berkomunikasi. Kedua, matapelajaran sejarah dapat dimanfaatkan sebagai wahana untuk proses sosialisasi dan enkulturasi nilai-nilai budaya bangsa dalam rangka membangun proses formasi Indonesia.

Ketiga, secara substansi pendidikan sejarah sebetulnya mampu menyediakan wacana yang luas mengenai proses integrasi di kalangan masyarakat Indonesia. Hal ini dimungkinkan karena sejarah Indonesia sangat diwarnai oleh sejarah hubungan-hubungan di antara elemen sosial dan budaya berbagai kelompok etnik dan sosial di Nusantara. Dengan demikian wishdom akan bisa dipetik oleh para siswa mengenai nilai-nilai yang berkembang dalam proses komunikasi lintas budaya tersebut yang pada gilirannya memperkuat proses hubungan antar elemen bangsa yang sebetulnya menjadi fondamen yang kokoh untuk integrasi bangsa Indonesia di masa yang akan datang.

Dalam hubungan itu pembelajaran materi Sejarah dapat digunakan sebagai alternatif pem- 
belajaran civic education. Hal ini sangat penting mengingat sekarang ini lembaga sekolah sedang mengalami krisis civic education ketika PSPB dan PMP serta P4 tidak ada lagi. Sementara itu, 'greget' Pendidikan Kewarganegaraan juga terasa kurang 'menendang'. Di satu sisi 'kewibawaan' Pancasila sudah tidak terasa lagi sejalan dengan bergulirnya euforia reformasi dan keterbukaan namun di sisi lain jika kita masih menginginkan Indonesia masih 'ada' maka civic education masih perlu 'diadakan'. Dalam hal ini pendidikan sejarah merupakan salah satu alternatif yang perlu dipertimbangkan.

Perspektif yang perlu dikembangkan dalam proses pendidikan sejarah adalah cross-cultural communication dan cultural reelativism. Jadi di samping menekankan pandangan bahwa proses terbentuknya bangsa Indonesia ( $a$ process to be Indonesia) tidak dapat dipisahkan dengan perkembangan historis hubungan lintas budaya antar kelompok etnis dan budaya yang ada di Nusantara tetapi juga bahwa penggambaran sejarah itu hendaknya menghindarkan diri sejauh mungkin prasangka-prasangka kultural dan etnisitas. Pendek kata pendidikan sejarah yang tepat akan memiliki nilai integratif bagi nasion Indonesia jika para guru sejarah memiliki kemampuan untuk mengajar dengan penekanan pada cross-cultural com-munication dan dengan meng-gunakan perspektif relativisme kultural. 


\section{Daftar Pustaka}

AB. Lapian. 1996. "Laut, Pasar, dan Komunikasi Antar-Budaya". Makalah disampaikan pada Kongres Sejarah Nasional Jakarta.

2003. "Warisan Kolonial dan Problem Batas Wilayah laut". Makalah disampaikan pada Diskusi Nasional Otonomi Daerah dalam Perspektif Sejarah Semarang.

Ariyono Suyono. 1985. Kamus Antropologi. Jakarta: Akademika Pressindo.

Ballard, Martin. 1971. New Movements in the Study and Teaching of History. Bloomingtob: Indiana University.

Benedict, Anderson. 1991. Imagined Com-munities: Reflections on the Origin and Spread of $\mathrm{Na}$ tionalism. Revised Edition. London and New York: Verso.

Carr, E.H. 1972. What is History. New York: Knoff.

Chris Barker. 2000. Cultural Studies: Theory and Practice. LondonThousand Oaks-New Delhi: Sage.

Collingwood, R. 1961. The Idea of History. New York: Oxford University Press.

Curtin, Philip D. 1998. Cross-Cultural Trade in World History. Cambridge: Cambridge University Press.

Dickinson, A.K. and P.J. Lee. 1980. History Teaching and History Understanding. London: Hinnemann.

Drake, Christine. 1989. National Integration in Indonesia:
Patterns and Policies. Honolulu: University of Hawaii Press.

E.L. Poelinggomang. 2003. "Masyarakat Suku Laut". Makalah disampaikan pada Diskusi Nasional Otonomi Daerah dalam Perspektif Sejarah Semarang.

Klooster, H.A.J. 1992. Bangsa Indonesia Menulis Sejarahnya Sendiri. Draf terjemahan oleh Suhardi.

Sartono Kartodirdjo. 1982. Pemikiran dan Perkembangan Historiografi Indonesia Suatu Alternatif. Jakarta: Gramedia.

1988. Pengantar Sejarah Indonesia Baru: 1500-1900: Dari Emporium sampai Imperium I. Jakarta: Gramedia.

_. 2005. Sejak Indische sampai Indonesia. Jakarta: Kompas.

Singgih Tri Sulistiyono. 2003. "The Java Sea Network: Patterns in the Development of Inter-regional Shipping and Trade in the Process of National Eco-nomic Integration in Indonesia, 1870s1970s". Dissertation at Leiden University.

Soerjono Soekanto. 1990. Sosiologi Suatu Pengantar. Jakarta: Rajawali Pers. 